J O U R A L O F

French and Francophone Philosophy
REVUE DE LA

philosophie française et de langue française

\title{
Améry, Arendt, and the Future of the World
}

\section{Anne O'Byrne}

Journal of French and Francophone Philosophy - Revue de la philosophie française et de langue française, Vol XXIV, No 3 (2016) 128-139.

\author{
Vol XXIV, No 3 (2016) \\ ISSN 1936-6280 (print) \\ ISSN 2155-1162 (online) \\ DOI 10.5195/jffp. 2016. 791 \\ www.jffp.org
}

\section{(c) EY-NC-NO}

This work is licensed under a Creative Commons Attribution-Noncommercial-No Derivative Works 3.0 United States License.

\section{UILIS D-Sunt}

This journal is operated by the University Library System of the University of Pittsburgh as part of its D-Scribe Digital Publishing Program, and is co-sponsored by the University of Pittsburgh Press 


\title{
Améry, Arendt, and the Future of the World
}

\author{
Anne O'Byrne \\ Stony Brook University
}

Of all the terms Jean Améry might have chosen to explain the deepest effects of torture, the one he selected was world. To be tortured was to lose trust in the world, to become incapable of feeling at home in the world. In July 1943, Améry was arrested by the Gestapo in Belgium and tortured by the SS at the former fortress of Breendonk. With the first blow from the torturers, he famously wrote, one loses trust in the world. With that blow, one can no longer be certain that "by reason of written or unwritten social contracts the other person will spare me-and more precisely stated, that he will respect my physical, and with it also my metaphysical, being." 1 In a vault inside the fortress, beyond the reach of anyone who might help - a wife, a mother, a brother, a friend - it turned out that all social contracts had been broken and torture was possible. His attackers had no respect for him, and no-one else could or would help. ${ }^{2}$

Already five years earlier he had had the experience of losing his world, the place where he was once at home. In March 1938, Nazi flags appeared throughout his native Austrian countryside and, even before he fled with his wife to France, he had lost the people, his people: "the schoolmate from the same bench, the neighbor, the teacher. They had become informers or bullies, at best, embarrassed opportunists." 3 He lost his language, and all the ties to meadows and hills, history and culture that hold together a world. A few years later, living in Belgium and working with a resistance group, he met a man who spoke in his familiar local dialect, and he was all but overwhelmed by a surging, intimate cordiality. He describes the experience of wanting to "address him in his, my language in order to then celebrate our regional patriotism and our reconciliation over a glass of wine." 4 But this was an SS man - off-duty, sleepy, merely complaining about noisy neighbors, but an SS man all the same. Améry writes: "At that moment I understood completely and forever that my home was enemy country and that the good comrade was sent here from the hostile homeland to wipe me out." 5 
But what can we make of the fact that later, in the 1960s when he was in his 50s, Améry used the same thinking of home and world to give an account of ageing? In the essays "Stranger to Oneself" and "Not to Understand the World Any More," it is not Nazi violence that bears down, setting us at odds with the world, but the hateful process of getting old. We experience it in our bodies, and in relation to the cultural life around us. We can no longer recognize ourselves in the mirror, and we can no longer understand the world that insists on changing around us. The world forges ahead, incomprehensibly, while our works and values become horribly oldfashioned and another world in which they had meaning seems to have slipped away.

The key is in its forging ahead. Exploring Améry's various invocations of the world and worlds - the world that lets him down in the experience of torture, the world he remembers in his state of exile, the world that makes itself strange to him as he grows older - turns up no way of answering this question. It is a catastrophe that the world should go on while your arms are being pulled from their sockets. It is an offense that the world of your childhood, the world that showed you who you were, should be destroyed or made alien to you. It horrifies us that the world becomes incomprehensible to us as we age. But we cannot understand these harms and the differences between them without understanding how worlds persist. Améry rejects a thinking that insists on the future, most explicitly Heidegger's thought that we are essentially future-oriented beings. For Améry, finally, there was no future. Yet worlds go on, and they do so not exactly because our being is futural, but because it is generational. This will be my argument here. We come to be and pass away but, in between, some of us bring new beings into existence, and, deliberately or incidentally, all of us pass on to them something of the works and values to which we devote our lives. We are relational, and world is the name for the relations that make and sustain us generationally, even as they shift and change with the movement of generations. Améry and others mention the ghosts of the dead who haunt us, but the feeling of being haunted makes sense only given the attention we already give to our own generation and the new generation coming up. The dead want their due. Améry and others remind us that the body declines, but that has its full significance only in the context created by the fact that my body comes from someone else's body, grows, changes, perhaps generates, changes some more, and declines even as others are born and grow, dying at last even as others continue to live.

Generational being sustains the world. This is the case for all worlds. It is the key to understanding what is the same and what is different about the three worldly experiences that Améry makes his themes: the shattering of the world he experienced in torture, the loss of world he underwent in exile, and the growing incomprehensibility of the world he experienced as he aged. It is a way to understand the genocidal harm to him, someone who 
became a Jew in the face of antisemitism. Does it mean forcing Améry's analysis to reckon with the future? Yes, it does. Does it mean forcing from the work of a writer famous for his relentless refusal to forgive a call for forgiveness, or insisting on finding in the darkness of his prose a flash of hope? No, it does not. The world goes on, for good or ill, and merely by going on it requires a response from us. Améry does not allow for such a requirement. I will argue that Hannah Arendt's question from "The Crisis in Education" is the place of reckoning: Will we, the young and the old, take joint responsibility for the world? ${ }^{6}$

\section{World and worlds}

When a Chicago couple, Benjamin and Lala Gazul, went on a trip to Europe in 1939, they visited the Jewish ghetto in Warsaw. As they often did on vacation, they brought along their movie camera and recorded several minutes of life on the streets there. Today, anyone can watch the home movie they made. ${ }^{7}$ In it, men talk to one another on the street. A small child stands up from her chair. An elderly man can be seen sitting in an upper room. A vendor arranges spectacles on a makeshift stall. Some boys tease a ragged man carrying a large bundle. A group of men and boys stand together and stare into the camera for long seconds. Shockingly, the film is in color, and it takes a little while to grasp that this was August 1939. Within weeks, the streets would be in flames. Soon each of those boys laughing in the sunlight would surely be dead. This mix of grandparents, middle-aged people and children would be gone. Their world was about to end. The world in which we live is so much the worse for that.

We recognize it as a world because of what is familiar and what is strange. Leaving one's home and talking to people on the street is a worldly thing to do. Anyone at all might show interest in a tourist with a fancy camera, or stoop to pick up a shopping bag, or even join in some casual cruelty to a ragged man, and here, in this time and place, it happens against a backdrop of signs written in Polish, in a street with a horse and cart passing. There are few women in view. Some bearded men wear long black coats. Others seem to be dressed for labour, and still others have starched collars and ties. That's how they did things then, there in the vanished world we glimpse in the Gazuls' film. We can understand it as a world because everything we see in it is a mode of being in the world. ${ }^{8}$

Améry speaks of his experience of exile mainly in terms of home, and of the alienation he experiences with the first blow from the policeman in terms of world, but the same structures are in place in each case. In one it is the loss of $a$ world-one's own world-and in the other it is the loss of the world. That is to say, his experience of exile might also be approached in terms of his world, the one in which he felt at home. After all, the essay "How Much Home Does A Person Need?" is not about home in Arendt's 
sense of the four walls that keep the outside world at bay, nor about real existing private homes where people live with their nearest kin and care for and love them, or loathe and hurt them, or engage in some happy/unhappy mixture of the two. Rather, it is about the feeling of being at home and the specific world-not the particular house-where that is possible. Home is security, Améry says. ${ }^{9}$ It is where we know we have a social place, as the successful china dealer from Bonn knew he had a place in his world; we know we belong to a culture, as the elderly, well-known poet belonged to German culture. ${ }^{10}$ Our world is meaningful. We know how to interpret the signs. It is where, as young Hans, Améry knew who he was. He was at ease in the traditional clothes he and everyone wore. He spoke dialect, had a familiar name, a group of friends, a culture.

A world is not a pre-set scene onto which the self arrives fully formed. Importantly, it not even an already accomplished backdrop against which the self gradually takes shape. Rather, we reconfigure the world by virtue of arriving into it, even as it gets to work on configuring us. It already consists of a set of signs being handed down, but we reorient them even as we receive that inheritance and learn to interpret those shared signs. It is a set of organic relations. Améry writes: “Just as one learns one's mother tongue without knowing its grammar, one experiences one's native surroundings. Mother tongue and native world grow with us, grow into us, and thus become the familiarity that guarantees us security." 11

What happened, then, when the Nazi flags appeared on his neighbors' farmhouses? His account of the loss comes in waves: he lost himself; his lost his world; that world died and was buried; worse again, perhaps it had never been his world at all. Améry never belonged to the world of a ghetto. Instead, his was made up of and by his Jewish family members and Catholic mother in their $20^{\text {th }}$ century Austrian milieu. It was essential to it that this was a world in which his parents could be married, and in which having a Yiddish- or Hebrew-speaking great-grandfather was merely a mildly interesting piece of cultural genealogy. This is the world that had grown up with and in him and that he in turn sustained by his life there. But in 1938, the essential elements that kept him secure disappeared. He writes: "I was a person who could no longer say "we" and who therefore said " $\mathrm{I}$ " merely out of habit, but not with the feeling of full possession of myself." 12 Jill Stauffer observes that Améry experienced the harm of torture as both a loss of personal sovereignty and also despair of all help. ${ }^{13}$ In the same way here, exile meant both the destruction of his distinctive singular selfhood and the breaking of the specific social relationships on which he relied.

The unfurling of a red, white and black flag marked the end of that world. Signals were crossed. Signs twisted themselves into new and unfamiliar shapes. Perhaps his neighbours experienced it as the beginning of something new that belonged to them more deeply than ever, or as an affirmation of their old world with its folk songs, woolen jackets, and 
antisemitism that could now be professed in public. Yet this is four years before the first blow from the torturer. Even as his own world betrays him, surely he can still trust in the world. Even though he can no longer be Austrian, surely other places-France, Belgium-can shelter him. The Tyrolian SS man will never help him, but surely there are righteous people in all nations, and if a moment comes when his wife is herself in hiding, and mother and brother are far away, surely there will be a friend to come to his aid. And if things really are so bad that he can count on no passionate intervention by someone who intervenes for him and him alone, or for those of his kind, at the very least he can call on a minimally dutiful fellow human being. If he cannot be saved out of love, someone will surely save him out of respect for his humanity. No?

No. As a cosmopolitanism, this conviction is not even second rate. ${ }^{14}$ It is simply an error. Améry lost trust in the world when the torturer's blow showed that there was no contract to which we were all signatories by virtue of being human, and there was no universal human recognition of a person's human dignity. As Améry discovered: “You are a human being only if you are a German, a Frenchman, a Christian, a member of whatever identifiable social group." 15 In the language I have been using, we can only call on the world from the midst of $a$ world; we can only belong to the world by virtue of belonging to a world. As he sat in a Vienna café in 1935, reading of the Nuremberg Laws, he realized that the state across the border had made him a Jew by social and legal degree, and had simultaneously pronounced his death sentence. This is how he became a Jew. For three more years he would continue to be Austrian and his world would continue to protect him as such. After all, it was still his country, and it still had laws in place to guarantee his citizen rights. But, he writes, "a home ceases to be a home as soon as it is not at the same time also a fatherland." 16 Insofar as we understand fatherland as a state equipped with the power and laws to protect our rights, this is a position shared with Arendt. For her, human rights are a matter of empty talk, since the only enforceable rights are civil rights, granted and defended by states. Once it had become intolerable or impossible to be both Jewish and Austrian, Améry had no state. And insofar as we understand fatherland as patrie, a patrimony distinct from others and equipped with a mechanism for its own transmission, it approaches an Arendtian view of culture, where the works of our hands make up a world that will outlast any one of us, a shared world that will continue to have meaning even when we're gone.

Améry eventually acquired a state-he marvels at the ease with which he could then cross borders, now that his papers are in order-but none of the official homes available to him are quite a fatherland in the patrimonial sense. He carried a line of ancestors with him out of Austria, but could only think of them as cursed, homeless errants like himself. He could no longer be Austrian Hans, but that identity had been developed in that stage of life 
when "one acquires a self" and so was irreplaceable, so he could not become Israeli Yochanan, nor easily sustain French-speaking Jean. ${ }^{17}$ Whichever one he chose, he would be obliged to continually cobble together a measure of worldliness, some sense of a world that might be his, in the face of his daily loss of trust in the world as such. He must proceed carefully, because he knows the precariousness of things. This is the deep bond to the despair his aging self feels in the face of a worldly culture that, after all, is merely doing what worlds do: change.

\section{The world's passing}

The world and our distinctive worlds are not simply natural givens, either for Améry or for Arendt. Améry invokes the organic image of native growth, but he does so as he prepares us for understanding the violence of being "completely uprooted" by events that had nothing to do with nature; 18 Arendt reserves the term worldly for precisely those human-made objects that resist the natural cycle of labor and consumption. Neither would ever affirm givenness as a way of claiming that how we find things is how they ought to be. Yet there is something given about the world and our worlds, since we are not permitted to choose where we come to be, and with whom. Both Arendt and Améry were born into Jewish families, and each acquired a self in a world where it never occurred to them to deny it. They and their neighbors and classmates knew they were Jewish. The young Hannah discussed antisemitic incidents at school with her parents, and student Hans was proud of his scuffle with a Nazi protester, but those struggles were experienced as part of the back and forth of a community's shared life and were no preparation for the moment when their worlds abruptly found their Jewishness intolerable. Those worlds had always acknowledged that they were Jewish, but now they forbade them to be anything else and marked them for destruction.

The change was violent, sudden, unheard-of, unfair, and unjust, but in all other respects it was like each of the changes that happen every day as the world goes on. It is like all the tiny changes that led to A's experience with her photo album in Améry's "Not to Understand the World Any More." 19 A. is in her 50s and is thinking unhappily about the clothes she will get for the new season. They will be toned-down versions of the latest thing, but what she would really prefer is an outfit she remembers fondly from her youth. Yet when she takes out the album and studies the picture of her younger self, the clothes are ludicrous: a foolishly long skirt, odd shoulder pads, a silly-looking hat. She discovers both that "old-fashioned things are funny and embarrassing because they have been known for a long time and we were there when they were overtaken by time" and also that "the outmoded immediately loses any ridiculousness when it is no longer merely looked at but remembered." 20 A. looks at the photograph in the world of today, 
and the image is a relic from another world that passed away bit by bit, season by season. But the memory of wearing those clothes places her back in that world, the world where she acquired her self, and, from that point of view, the fashionable dresses of today are the ones that seem grotesque. We are all exiles from youth in the same way that Améry became an exile from Austria, but the banal experience of aging happens in small, scarcely noticeable increments: the change of skirt lengths from one year to the next; the fall and rise in popularity of the memoir as a literary form; the young philosopher's comment that nobody reads the Republic these days, it's all about the Laws; the switch from phone calls to texts to tweets to swiping left and right.

The changes may be jarring, but hardly violent. We all have the feeling that they sneak up on us, but we can't quite claim that they are sudden. Untold generations have aged before us and tried to tell us about it, and the same thing happens to everyone who lives beyond youth. This is not a matter of justice. Everyone ages. But one can age badly or well, and "one ages badly in exile," where alienation is piled upon alienation. ${ }^{21}$ The young exile has lost the past and must struggle to decipher a meaningful present, but who knows what is yet to come and what he will turn out to be? The future is his. Not so the one who is aging, exile or not: he is no more than who he is. For him, there is no future.

This is the point where Améry's attunement to the dynamic two-fold understanding of the self falters. Torture was experienced as a harm to sovereign self and the self who must call on others for help; exile was a loss of the singular self and the distinctive cultural and social relations that made it singular; age might be an intensification of self and a gesture towards what follows, but for Améry it is the loss of self and world. He is committed to the thought that one acquires a self in the midst of others, according to the various modes of being that make up one's own distinctive world, but now it appears that the acquisition eventually comes to a halt, and always sooner than we would wish. Each of us when young starts off with a line of credit we granted ourselves, an advance which year by year is used up as we do this rather than that, become this rather than that until at last-though long before the end-we feel the onset of age and begin the realization that the credit is used up and this is who we are. We become deathly fixtures in a lively world that does not stop changing. Why does it change, relentlessly? Dwelling on the congealed selves of the aged allows Améry to turn away, disconsolate, from the fact that new beings enter the world all the time and that their very newness sustains the world. He knows that he received his language and his culture from those who came before and that he made it his own; he knows also that the generation that followed received their world and proceeded to make it their own too. Unable to confront the relation between those too, he is caught in what he experiences as "a loss of ego and world never to be replaced by anything or through any means." 22 


\section{The world of culture}

I lose ego, I lose world, and yet the world goes on.

"Not To Understand the World Anymore" is an essay on getting culturally old. It is an essay about signs and time. For Améry, the sign system in which I come to be becomes my own individual system made up of the clothes, music, poems, theories, ways of being that first allowed me to make sense of my world. For a brief historical moment it coincides, more or less, with the dynamic supersystem that is the spirit of the age, and then begins to fall behind. The signs begin to change, new systems intervene and before long we face the choice of either setting up camp in our old, familiar world, intransigent and conservative, or trotting to keep up with what's new. All the work that went into learning the old signs has been for naught, and all the work we'll put into learning the new ones will never really pay off, since we will never again be "in." There is no sense that all this might be a matter of the moral or cultural progress of humankind; instead, culture lurches forward, today's supersystem destroying those of yesteryear and the year before, and overpowering all individual systems. We drop away. Améry writes: "Every withering away of a cultural sign system is death or the symbol of death. The imperative to die is witnessed by the aging. But right after it an imperative to become emerges, completely without them." 23

Arendt writes about time and culture in the same era ("The Crisis in Culture" was written in 1960) but her approach initially seems to offer little help. For Arendt, culture is experienced in two ways, according to two modes of being in time. In one sense, our lives happen according to the cyclical rhythms of growth and decay, labor and consumption, and culture too may be the production of consumable objects that appear and then disappear according to the same cycles. This is mass culture, and to concentrate on it seems to compound rather than resolve Améry's worries. Hollywood was her preferred example, but the fashion industry with which A. struggled would have worked even more effectively. The movie industry produces a new blockbuster, we all have fun watching it, and then forget about it as we look forward to the next one, due for release the next weekend. The fashion industry generates favored cuts and colors each season, we enjoy the glossy pictures and buying and wearing the new clothes, only to dispose of them as the next season arrives. We want a lot of movies and a lot of clothes, new ones every time, and for Arendt it is mass culture not only because so many of us enjoy it but because our huge appetite for it demands that it be served up in enormous quantities. In The Human Condition she regrets that the spirit of the time was reducing all human activity to some version of labor and consumption; 24 here, in "The Crisis in Culture," she sees the same spirit giving rise to an ephemeral culture that places no demands on us. Too busy consuming the stream of 
culture products, we are never expected to learn their history and methods, as Améry's culturally educated person feels obliged to do, or to pause and evaluate the work, as Arendt wishes we would. To lapse into this mode of being in time may be quite pleasant, and may mean less anguish in the face of change and an acceptance of death as part of life, but for Améry, the sacrifice of worldliness is surely too high a price to pay.

This is certainly true of Arendt, who turns to a second temporality. In another sense, she argues, a human life cuts a straight line through the cycles of nature. This is not a line that leads from birth to death and beyond to a transcendent eternity. It is, rather, a worldly life, its escape from the natural cycle made possible by a world that can provide some resistance to consumption and decay, and that provides a site for meaning that will last longer than any one of us. This life, and the world through which it traces its line, may or may not form a segment in a great line of historical progress. In either case, it won't last forever and it cannot offer immortality but, crucially, it allows us the possibility that something of us might stay, for a while. Perhaps what remains will be the work of our hands, as the Human Condition would have it, or perhaps, in the language of the culture essay, it is more important that it be the work of an artist, "the authentic producer of those objects which every civilization leaves behind as the quintessence and the lasting testimony of the spirit which animated it."

Yet objects rarely preserve themselves. The earth sometimes gives up ancient pottery shards and carvings in which we recognize the work of human hands, but that discovery only ever marks the beginning. We have to study the orphaned objects for clues in order to reconstruct the world in which they had their first meaning, and it is difficult to know if this is the quintessence of a civilization or the detritus that happened to fall into a bog one day. If objects produced by humans are what constitute an enduring world, then we must understand object broadly and include institutions under that heading. This becomes clear in the moments in Arendt's work when culture brushes against politics; what she has in mind as the sites of preservation and the bearers of lasting testimony are the institutions of public life. We build and must work to sustain institutions, which in turn protect and preserve the things we make in the face of the disposability of mass culture. My grandmother's dresses are long gone, but the Costume Institute at the Metropolitan Museum of Art has clothes that are 700 years old; royal families preserve the robes and insignia of power over centuries; the Catholic Church owns textiles that date from the time of Christ.

The preservation of relics can only be part of the story, and not the most interesting part. It contributes the possibility of a future to Améry's otherwise future-less scheme, but he would be less than compelled by the possibility of the artworks of his youth being included in a display of the curios of yesteryear. It is a deathly sort of future. Arendt's more substantial contribution is her grasp of the imperative to die and the imperative to 
become as simultaneous, overlapping, life-long commands. We are mortal but also natal beings, and the fulfillment of that finitude can only come in our mortal and natal-that is, generational-encounter with the world. Améry would agree that we each owe the world a death, but for Arendt this is inseparable from the fact that, by virtue of having been born, we also owe the world something of our natal newness.

\section{Responsibility for the world}

This generational dynamic is worked out most thoroughly in the essay "The Crisis in Education." Education - what teachers do in schools, what parents do at home, what the older generation does in myriad ways-must rest on the acknowledgement that the world is constantly replenished by the arrival of new beings. Their newness means that they can do things their elders never imagined, and their energy will gather strength as that of their elders diminishes. What Améry experiences as demoralizing is also terrifying. How can the old ones bear to expose the world they have worked so hard to build and care for to the thoughtless, clueless power of a new generation? So we respond by insisting that education be conservative, precisely in order to protect the world. Yet the world belongs to the old precisely because of the work they did to develop and sustain it. If they give up the work now, as eventually they must, the edifices they erected in stone or in learning will soon be worn away by use, or will crumble thanks to the natural ravages of time and cultural amnesia. Any world, and all its objects and institutions, are made by us and so already exposed to forces of destruction. What will become of them unless they are renewed and rebuilt by those to come? Thus education must also be conservative in another way, protecting the natal creativity of the young from the constraints that the old will try to put on it.

We occupy the world together, and sustaining any world will necessarily be a joint effort among people born at different times. Learning is essential-education has to equip us with some knowledge of the worldbut way in which the young are inculcated into the shared body of worldly knowledge is informed by the question of responsibility above all. Arendt imagines a scene. A parent, disgusted at the state of the world, tells his children:

In this world, even we are not very securely at home; how to move about in it, what to know, what skills to master, are mysteries to us too. You must try to make out as best you can; in any case you are not entitled to call us to account. We are innocent, and we wash our hands of you. 25

For Arendt, this would be an utter failure to take responsibility, understandable only if the speaker has failed to make the distinction between moral responsibility and worldly or political responsibility. The 
parent may be right: he did not make the world the way it is, and he is not the perpetrator of all or even any of the crimes against it. Yet the world presents itself as it is, in its givenness, and that is the call to which we must respond. We must become, we must die, and we must either take or take on the world as we find it. The times are always out of joint, and while Hamlet seems convinced that it is up to him alone to set them right, it is a human condition. Arendt encourages us to imagine a different scene:

The educators here stand in relation to the young as representatives of a world for which they must assume responsibility although they themselves did not make it and even though they may, secretly or openly, wish it were other than it is....Anyone who refuses to assume joint responsibility for the world should not have children and must not be allowed to take part in educating them. ${ }^{26}$

The responsibility is broad and deep, and we should not be deceived by the joint nature of it. The non-reciprocal process of bequeathing the world and inheriting it is perilous, fraught with the dangers of stultification on the one hand and sheer destruction on the other. The interests of one generation will not be the same as those of the generation they generate. If the young are educated in awe of a glorious past, they will never come into their own; if they come of age with no understanding of the work of their forebears and no appreciation of their own power, they might ruin everything. In all her writing, Arendt is more concerned about the former than the latter. Without the power to start anew, there would never come a revolution.

After 1945, the world for which we are asked to take responsibility includes the exile, torture and death of millions, and also, as Améry piercingly puts it, the German revolution that did not happen. ${ }^{27}$ One strand of Arendt's thinking invites us to let natal newness express itself in forgiveness and the creation of a new beginning in the world, but this is an invitation Améry could not possibly accept. However, another strand would carry us from the provocation of the-revolution-that-never-happened into the darkness of those twelve years, not in order to find sparks of hope but to understand how the human struggles of public, political life succumbed to the conviction that one group-the German people-could decide with whom they would share the world.

\footnotetext{
${ }^{1}$ Amery, At the Mind's Limits, 28.

2 lbid., 27.

3 lbid., 42.

${ }^{4}$ lbid., 49.
} 
5 lbid., 50.

${ }^{6}$ Hannah Arendt, Between Past and Future: Eight Exercises in Political Thought, 170-93.

7 See the film at https://www.ushmm.org/research/research-in-collections/overview/film-andvideo.

${ }^{8}$ Shannon Hoff captures the role of having a world aptly: "Human lives are rendered meaningful by the specific activities in which they are always involved and the contexts of identification to which they belong, by the existence of specific worlds that take shape in their own way, according to their own logic, not simply as produced by individual choice; indeed these worlds, contexts, and activities are the conditions under which individual choice can become a possibility in the first place. Hoff, "Rights and Worlds," 356.

${ }_{9}^{9}$ Amery, At the Mind's Limits, 47.

10 Ibid., 59.

11 Ibid. , 48.

12 Ibid. , 44.

13 Stauffer, Ethical Loneliness, 15.

${ }^{14}$ Amery, At the Mind's Limits, 56.

15 Ibid., 84.

16 Ibid. , 55.

17 Ibid. , 97.

18 Ibid. , 45.

${ }^{19}$ Améry, On Aging, 78-102.

20 Ibid., 80.

${ }^{21}$ Amery, At the Mind's Limits, 60.

${ }^{22}$ Améry, On Aging, 97.

${ }^{23}$ Améry, On Aging, 101.

${ }^{24}$ Arendt, The Human Condition.

25 Ibid., 191.

${ }^{26}$ Ibid. , 189.

${ }^{27}$ Amery, At the Mind's Limits, 77. 